\title{
Gene discovery for complex diseases using exomic sequencing: identifying pancreatic cancer susceptibility genes
}

\author{
Alison P Klein ${ }^{1,2}$ \\ From Beyond the Genome: The true gene count, human evolution and disease genomics \\ Boston, MA, USA. 11-13 October 2010
}

Traditional methods of gene discovery, candidate gene and linkage approaches, have yielded very few pancreatic cancer susceptibility loci, such that genetic basis of $\sim 90 \%$ of the familial clustering of pancreatic cancer is unknown. The recent advances and cost reductions in genome sequencing have enabled us to identify pancreatic cancer susceptibility genes through exomic sequencing patients with a family history of pancreatic cancer. Individuals that have an inherited tumor suppressor gene often lose the wild- type allele through loss of heterozygosity or somatic mutation. Therefore, we examined a patient's tumor and germ-line DNA for genes with evidence of both inherited and somatic variants that were likely to result in the absence of a functional protein in the patient's tumor. We also analyzed data on normal genetic variation in published databases and in individuals without pancreatic cancer. These analyses identified $P A L B 2$ as candidate pancreatic cancer gene. The role of $P A L B 2$ in familial pancreatic cancer was validated by studying an additional 96 pancreatic cancer patients. Large-scale follow-up studies of over 500 familial pancreatic cancer patients are currently underway.

\section{Author details}

'Departments of Oncology, Pathology, The Sol Goldman Pancreatic Cancer Research Center, The Johns Hopkins Medical Institutions, Baltimore, MD 21231, USA. ${ }^{2}$ Department of Epidemiology, The Johns Hopkins School of Public Health, Baltimore, MD 21231, USA.

'Departments of Oncology, Pathology, The Sol Goldman Pancreatic Cancer Research Center, The Johns Hopkins Medical Institutions, Baltimore, MD 21231, USA

Full list of author information is available at the end of the article
Published: 11 October 2010

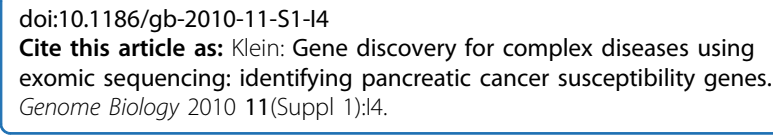

Submit your next manuscript to BioMed Central and take full advantage of:

- Convenient online submission

- Thorough peer review

- No space constraints or color figure charges

- Immediate publication on acceptance

- Inclusion in PubMed, CAS, Scopus and Google Scholar

- Research which is freely available for redistribution

Submit your manuscript at www.biomedcentral.com/submit
BioMed Central 